\title{
The changing face of the farming community: Lone Star Farms
}

TOM STURGESS and WAYNE ANDERSON

Lone Star Farms, Level 2, 295 Trafalgar St., Nelson, NZ

opsco@xtra.co.nz

\section{Introduction}

Firstly, we would like to thank the NZ Grasslands Association for giving us the opportunity to participate in the 75th Conference, and congratulate them for the valuable contribution that they have made over the years to New Zealand pastoral farming. It is heartening to see that the passion for grasslands and rangelands, as exhibited by the likes of Levy, Flay, and Hudson, long ago, is safely in the capable hands of the young guns who will lead the Association further into the 21st Century.

Lone Star Farms, which was formed in 1996, is not a corporate farm in the classical sense, but a family farm run on corporate lines, currently comprising 10 properties throughout the South Island. Four of these properties are partially pastoral leasehold, five are freehold, and one is Puponga Farm Park at the base of Farewell Spit in NW Nelson, which is leased from the Department of Conservation. We are solely a sheep and beef cattle enterprise, with a geographic range which gives a good spread of climatic and market risk. Last winter we carried approximately 128,000 sheep and beef cattle stock units, and we are budgeted to increase next year to $140,000 \mathrm{su}$.

There are nine Farm Managers and generally 20 other permanent farm staff. We have a Head Office, situated in Nelson, which, on the farming side of the business, consists of one Operations Co-ordinator and the equivalent of 2.5 administrative and clerical staff, giving a ratio of one farm staff member to $4600 \mathrm{su}$, and one support staff member to $40,000 \mathrm{su}$.

The first consideration once we assume ownership of a property is to address subdivision, soil fertility, pasture species, and animal genetics, and once these are taken care of, we begin utilising our management strengths.

In terms of Land, Labour, and Capital, it is the Labour component (i.e. managerial expertise regarding timing, decision-making and control) which will take us forward, once the basic building blocks of productivity are in place.

\section{Lone Star Farms Philosophy of Corporate Farming}

As far as a philosophy is concerned, we don't really have one, but if we did it could probably be summed up as - keep it simple and get on with it! We don't have a Mission Statement, and without presuming that size gives us any authority over anything, it would be fair to suggest that we subscribe in principle to the adage - "think globally, act locally".

In the first instance we are Pastoralists. Members of the second oldest profession, and as such, as a Group, we need to get up to speed regarding improved pastoral management techniques. We also need to make greater use of available proven scientific technology. Having said this, however, whilst still coming to terms with the information and technology of the 21 st Century, we are really still trying to learn and apply some of the relevant practices from the last Century. In this we need to make greater use of IT, both for communication and decisionmaking, and to date we have hardly scratched the surface.

We need to up our efforts towards a more professional projection and differentiation of our products as healthy and desirable foods and fibres. In this we need to be aware of future world demands for protein. We are aware that, in terms of red meat protein, the security of New Zealand's current sheep meat markets is where we need to be concentrating our efforts in the short to medium term, and consistently provide these markets with high quality, grown to specification, lamb products. To produce for these markets, which are and will be ever more discerning and demanding, we as a Group need to become more market driven, while at the same time maintaining our production focus.

We need to become more involved with all major players in terms of our genetics/breeding and processing/ marketing networks. In this regard we need to tighten up our currently loosely integrated red meat supply chain, which is weak and disconnected when compared with that of our white meat competitors.

We need to encourage and expect continued effort from our physical and social scientists in terms of research collaboration, and we need to articulate the immediacy of marketing and extension progress pertinent to technically applicable results. In this regard, it is particularly pleasing to have AgResearch re-enter the real world of agricultural endeavour. With their help, and the help of others in the field, we need to have a greater understanding and less fear of the benefits of gene technology.

We need to have a greater understanding and less fear of current and looming environmental issues, and the possible downstream compliance requirements that may emanate from these. And maybe the wider industry needs a greater acceptance of models whereby overseas investment is not discouraged. 
Even though markets and the weather conspire to deflect us from our aims and objectives we must counterconspire to not let this happen.

Similarly, as Pastoralists, we need to take a re-look at our properties. Maybe we need to look at them for what they are. Not only as somewhere where we as humans live and do business, but also as habitat for the animals we farm - and for which we have a welfare responsibility - and all the other plants and creatures which, by way of their diversity and vitality, give our properties their special and unique character.

Sometimes we tend to lose sight of these inherent qualities, and maybe we become overly focused on excessive Economic Farm Surpluses, often to the detriment of the natural environment. Lone Star Farms has an advantage in this regard, but unfortunately for others it is often difficult to separate out the capital needs of farming from the capital needs of land ownership.

As Pastoralists, whatever visions for the future we have over the next decade will be overlain by the urgent considerations of climate, water, and energy, which, in the New Zealand context, are often closely intertwined, both naturally and emotionally. (As an aside, maybe as a nation we need to be openly and objectively debating the potential comparative advantages of fission/fusion thermo-nuclear power as a source of energy.)

As a Group however, we will need to concentrate more on these issues in coming days as they pertain to on-farm, and get on with putting in place measures to assure for ourselves a viable commercial and environmental future.

Our investment in infrastructure (such as fencing, fertiliser, genetics, and technology) so far has not been insignificant, and, having been made, we feel that the prime resource that will drive our pastoral farming enterprise to the next level, will be the commitment, knowledge, and acumen of our Farm Managers.

For all of us, change will be the challenge.

Lone Star looks for people who have expectations and abilities above the traditional farm manager model; i.e. those who are soundly based in terms of practical skills and desire to have a wider appreciation of agribusiness. Recruitment in the past used to be solely based on the advertising of positions. Now, selected people are identified and invited to apply, although we regularly receive unsolicited requests from potential farm managers for positions, and these are held on a database for future consideration.

We regularly talk to the tertiary sector e.g. Lincoln University, to encourage a positive view of farming as a career opportunity, and to offer graduates and diplomates permanent and casual work where and when we can. We employ female shepherds on our properties and find that they bring a real raft of positives to our business by way of their different approaches. In terms of orderly succession of staff, within a mobile agricultural employment market, we endeavour to identify suitably qualified people well before positions become vacant.

Farm managers are remunerated in bands acknowledging both responsibility and the number of stock units carried. They undertake an annual review with the Owner based on the previous year's financial and productive results, and remuneration, conditions of employment, and discretionary bonuses are negotiated at that time. In the future the reward tool of incentive bonuses may arise once Blocks are in a position to realistically support them. All other staff have annual reviews with their respective Farm Managers based on the same criteria.

Like most rural operations, our staff are involved in all spheres of recreational, volunteer, and community work such as search and rescue, rural fire brigades, school committees, dog trials, rugby, rodeo, wood chopping, play centres and kindergarten, church, dance sports, and the like. As well as this, a couple of our families are active in distance learning.

Lone Star Farms has three tiers of staff: Farm Managers; Senior staff; Junior staff.

Training programmes for the first two tiers are optional, but training is compulsory for Junior staff, and all must do some form of AgITO training leading to a recognised qualification. These people also get instruction in all practical facets of the business, both on and off property.

Programmes offered to Farm Managers and Senior staff include courses in rural leadership, project management, time management, planning, problem solving and decision making, etc. All Farm Managers are in varying stages of becoming broadly based computer literate, and all are involved in programmes such as Farmsafe, Growsafe, First Aid, ATV Safety, ACC/OSH, etc. Because we see some relevance in this, all Farm Managers also compulsorily receive the Dairy Exporter and the Organic NZ publications.

Each year a Farm Manager is sponsored to undertake 10 days study travel in Australia, based around the Sydney Royal Show at Easter from which they produce a report. Two Farm Managers are selected to go to the NZ Grassland Conference when it is held in the South Island, and others attend the National and Southern Field Days.

Our Managers have responsibility based on accountability. All Farm Managers are responsible for and sign off on their own budgets and cashflows (which contain separately designed animal health and fertiliser plans), and which they draw up in conjunction with their individual consultants, with input from the Operations Co-ordinator. All expenditure invoicing and revenue receipts are coded by the Farm Manager and then sent to 
Nelson Office for processing on a monthly basis. Within a fortnight, a print out is returned for their confirmation, showing monthly transactions in the form of a Journal, monthly P\&L, and a year to date P\&L. They then return a cashflow analysis based on this showing Actual vs. Budget in terms of permanent or timing differences. Cash control is very much the nub of the financial component of our business.

Each Farm Manager furnishes a weekly report, and a monthly livestock reconciliation, which is their receipt to the Owner for all the livestock under their control.

Formal arrangements with our Suppliers and Processors, regarding our main Revenue and Expenditure items, are negotiated on a Group basis from Nelson Office, with most other transactions at the discretion of the Farm Manager.

Stock for sale are offered within the Group in the first instance, then to those with whom we have pre-arranged agreements, then if no progress is made, canvassed for private sale, and then to public sale. All inter-company transactions are between the Farm Managers on current market value on the day, no binding arbitration is entered into, and if no deal is reached, then the above process kicks in.

All properties within the Group are regularly bench marked for identifiable and relevant parameters, with measurements conducted on-farm through the use of electronic scales, modern drafting systems, and with increasing use of electronic identification.

Two properties are in the Sheep for Profit programme, and two are on Farmax. All properties use the Endeavour mapping programme, with two also using Resolution. All properties are "twinned" with a farm consultant, with whom they have co-responsibility for budgets, cashflows, and feed budgets, based on four planned onsite visits per year, and two separate Pre-Budget and final Budget consultations, with other communication as and when required. Access to other technical support resources is available through our agronomic, fertiliser, and animal health specialists and others as needed. The role of Operations Co-ordinator is one mainly of support and obviously co-ordination. We don't have overseers, supervisors, or the like. Within a given policy framework and with the right tools at their disposal, we pay Managers to manage.

Integration within the Group is important. Each geographic grouping have their own regular planned farm meetings and social gatherings. Apart from two on-site Monitor Farm days, Managers come together for a midwinter meeting and socialisation, and a pre-Xmas meeting and social which is held in Nelson for all the Farm Managers, support staff, their partners and school-age and younger children.

Internally there is a regular Friday e-mail which comes from the Office keeping all in touch, and we also publish a quarterly newsletter to which, amongst others, all Farm Managers contribute and which is circulated to those who have some interest in our organisation.

\section{Prime Focus: Prime Lamb Production}

Our main function is pastorally-based lamb production. Wool and beef are ancillary to the main aim but are no less important in terms of a second tier income stream.

Perendale and Romney/Texel ewes are mated to sires of the same breed for replacements, and SufTex and Poll Dorset sires are used for terminal lamb production. This programme makes use of hybrid vigour, and taps into the potential of Myomax and LoinMax genes. Godley Peaks at Lake Tekapo runs Merino and $1 / 2$ bred ewes mated to Merino and SufTex sires.

All sires, both sheep and cattle, are selected using SIL records and EBVs in the first instance for identifiably positive traits, e.g. birthing ease, survival, growth rate, parasite resilience, retail product yield, etc. In the case of rams we select for weaning weight and liveweight at 8 months, so long as all other recorded traits are positive. Selection then is on phenotype. When selecting Bulls we use the 7 T's method - Teeth, Topline, Tail, Testicles, Toes, Type, and Temperament.

The overall business aim in the medium term is for $145 \%$ lambing (survival to sale). This percentage will allow us the scope to select high quality female replacements, which should give us the opportunity to consider mating approximately $50 \%$ of our maternal dams to terminal sires. One of the key performance indicators in the selection of our replacements in the future could be to have our ewe hoggets, whether lambed or unlambed, at $60 \mathrm{~kg}$ liveweight by mid-January.

Most of our properties have come from lambing percentages in the mid 90s and the low 100s, and over the last few years we have made progress to the extent that we now have three already into the mid 140 s, with the remainder of the Crossbred ones not far behind. The two properties with the lowest lambing percentages are both in the low 120s, but, given the unique landform challenges they face, we are more than satisfied with their levels of performance at this stage.

Carcass production is based on an outdoor, milk- and grass-fed system. Our aim is to increase lamb growth rate to achieve slaughter liveweight within the shortest possible timeframe. Our current average is $60 \%$ prime in 160 days, but the immediate aim is to get to $80 \%$ prime in 120 days (i.e. $300 \mathrm{~g}$ /day from a birthweight of $4 \mathrm{~kg}$ to a liveweight of $40 \mathrm{~kg}$ ). This will not only enable us to sell on a better Schedule/Pool, but also provide us with the opportunity to take on a second cut of heavier liveweight store lambs for finishing, if we can, before our selfimposed cut-off date of Anzac Day. This is when the 
rams go out on most of our properties.

We are aiming to achieve $>44 \%$ yield of liveweight post-weaning to carcass weight, and $>56 \%$ yield from carcass weight to saleable product, with a yield distribution of $>22 \%$ for Leg and $>16 \%$ for Loin. Currently we are only achieving just $>14 \%$ yield for Loin, but we are working with our Breeders on improving this. If this improved yield performance can be translated across to a $17 \mathrm{~kg} \mathrm{YM} / \mathrm{YX}$ lamb carcass (within a range of $14.5 \mathrm{~kg}$ to $18.5 \mathrm{~kg}$ ), which is what our processors tell us, by way of price signals, that the market wants, then maybe we will be some way down the path to achieving profitability.

The underpinning basis of this whole model, however, relies on us growing high quality grasses, legumes, and forages, and having the relationship between reproductive and productive performance, stocking rate and class, and the utilisation of kilograms of high ME dry matter grown, forming the nexus of our whole operation.

\section{Barewood Station}

At this point we would like to acknowledge the original inhabitants of this land. We would also like to pay tribute to the efforts of Charles and James Reid and their forebears in making Traquair into the highly regarded property that it is today. We would also like to pay tribute to those involved over the years at Barewood, from 1856, when Sutton took up the lease of Run 79 as it was then known, down to the previous owners from whom we took over; Cliff Tapper and Gary Clarke at Barewood, Russell and Jeanine Cotton at Strathmore, and Steve and Michelle Holland at Flat Stream. In fact we would like to acknowledge all of the farming families and their staff who have over the years added to the rich rural tapestry of Otago - to people such as the Reids and their ancestors who, like mine, were amongst the earliest Settlers to the Province in 1848 . We would also like to acknowledge the gold mining activities of the 1890 s - early 1900 s which saw the establishment and eventual demise of a small village community at the Reefs.

Barewood is a triangular shaped property bounded by the Taieri River in the NE and Deep Stream to the S, and at 6,300 ha and with 22,000 Romney Texel ewes is similar in size to Traquair. Soil types are mainly Wehenga YBEs, and Pukerangi and Matarae YGEs, with their distinct managerial requirements, however, I will leave further discussion on this and Development to Marty Deans, the Farm Manager, and Simon Glennie, the Monitor Farm Facilitator, who also happens to be on the Conference organising committee.

To further explain Simon Glennie's role as Monitor Farm Facilitator, within Lone Star we have our own internal Monitor Farm. We have just completed 4 years at Rainbow Station in Marlborough and have now moved to a 4 year programme at Barewood, which is overseen by the Manager, the Facilitator and the Operations Coordinator. Regular site visits are undertaken by the other Farm Managers, a core group of suppliers and advisors, and other invited contributors. Physical and financial targets are set based on key performance indicators, and these are bench marked against our other properties.

Although largely modified from what it once was, we hope that we would be able to put our own positive imprint on this landscape in the time that we have here.

\section{Grasslands Conference Topic - "It's Not Easy Staying Green"}

In this regard, we could also add that "we can't be Green if we are in the Red", however we have an underlying policy of treating our farms as a habitat, not only for ourselves and the animals under our care but also for the other naturally-occurring plants, insects and animals.

We are involved in water use and water quality through the Hakataramea River Users Group and the Mackenzie Irrigation Co., and follow with interest and support the work of the Taieri Trust.

There is a possum contraceptive research programme being run at Puponga, the Black Stilt breeding programme administered by DOC is on Godley Peaks, and a Powellaphanta snail protection project is at Paturau in Golden Bay. Various outside agencies undertake work on most of our properties in one way or another; e.g. seismic recording at Quartz Range in Golden Bay, stoat trapping at Rainbow, porina monitoring at Barewood, and wallaby control at Caberfeidh in the Hakataramea Valley.

We are involved in the preservation and restoration of local history at Patuki on D'Urville Island and at the Reefs at Barewood, limestone cave protection at Paturau, sub-alpine flora preservation at Mt Albert at the head of Lake Wanaka, and an indigenous production forest at Puramahoi, where planting began 10 years ago.

We have undertaken work regarding animal welfare in the form of non-tail docking of lambs, and we are involved in rare breeds conservation with a small flock of Pitt Island Merinos.

Energy saving measures such as solar panels and windpowered generation are being investigated, and quality testing of water entering and leaving our properties is currently being undertaken. We are in the early stages of nutrient budgeting, and are following with interest methods to control excessive nitrous oxide emissions from pasture.

We are cognisant of the overuse of fossil fuels, $\mathrm{N}$ fertilisers and chemical sprays, and we are in the early stages of working through systems to mitigate any harmful effects of these. Partly as a response to becoming 
aware that land cultivation has the potential to release approximately $22 \mathrm{tCO} 2 /$ ha into the atmosphere, we are increasingly investing in zero tillage where we can.

We are involved in planting various tree and shrub combinations for shelter, shade, and habitat, (with the added advantage of providing bird and bee food, and wood fuel, etc.). Some of the species so far planted are Eucalypts, Acacias, Pittosporums, Coprosmas, Flax, and Toi Toi. At Barewood we are retrospectively identifying remnant areas of Snow Tussock that we may be able to protect in a sustainable way. We also have some relatively large plantings of conifers (mainly Pinus radiata) which, apart from the timber resource, may have future value in terms of carbon sequestration. At the other extreme there is ongoing wilding pine eradication being carried out at Caberfeidh.

Earthworm farms are being established at Barewood and at Puramahoi in Golden Bay, and these will be replicated on other properties.

Puramahoi, which runs a small number of Wiltshire sheep and Lowline cattle, is Certenz Organic accredited for both horticultural and agricultural produce, and Lone Star has qualified expertise in Permaculture, as it relates to pastoral systems, within the Group.

And like most other farming operations in NZ, we undertake our own widely diverse noxious weeds and noxious animals control programmes.

Depending on one's perception of "green", we feel that we are making some progress along the pathway towards a more balanced approach to our farming operations. We still have a very long way to go though. Within the gloom of international conflict, global pandemics, and political ineptitude however, we are confident that we can play our part in — "going Green, being Green, and staying Green!"

\section{Conclusion}

Lone Star Farms has an intention to use its corporate structure to integrate a balance of land, financial capital, and human capital, with the aim of providing a sustainable living area for our people, the livestock they tend, and all the other forms of life that share their space with us. To do this we are focused on ensuring that a strong environment is maintained, managed by a highly competent team; and we are guided by the principle that by making best use of our pastoral skills and knowledge we will be able to face up to our current and future ethical obligations and responsibilities with confidence. Not only for ourselves, but for the benefit of those who come after us. 